\title{
ISLAM DAN DEMOKRASI: PANDANGAN INTELEKTUAL MUSLIM DAN PENERAPANNYA DI INDONESIA
}

\author{
Kiki Muhamad Hakiki \\ Dosen Fakultas Ushuluddin IAIN Raden Intan Lampung \\ J1. Letkol. H. Endro Suratmin Sukarame Bandar Lampung 35131, Indonesia \\ E-mail: m_hakiki@yahoo.com
}

\begin{abstract}
Democracy is one interrested topic of discussions especially in relation to Islam. Many questions emerge associated with Islam and democracy such as: Does Islam has the concept of democracy? Does democracy compatible with Islam? What is the Muslim scholars response to the issue of democracy? This paper will investigates these questions using library research. This study discoveres that there are different opinions among Muslim scholars in relation to democracy: some said that democracy is compatible with the Islamic doctrine, another scholars stated otherwise, while the others stand between the two. Islamhas a term that resemble with the term democracy that is shurāa, with different principles. In regard to the application of democracy in Indonesia, the majority of Muslim scholars in Indonesia accept positively to the concept of democracy and considered it to be compatible with the Islamic doctrine.
\end{abstract}

\section{Keywords:}

Islam; democracy; shurā; Indonesia.

\begin{abstract}
Abstrak
Perbincangan seputar tema demokrasi memang menarik, terlebih jika dikaitkan dengan doktrin agama dalam hal ini Islam. Maka berbagai pertanyaan pun menyeruak; apakah demokrasi mendapatkan tempat yang layak dalam Islam?; apakah pesan-pesan demokrasi sesuai dengan ajaran Islam?; apakah Islam sendiri mempunyai aturan yang sama dengan demokrasi?; dan bagaimana respon para sarjana muslim terhadap isu demokrasi? Pertanyaan-pertanyaan inilah yang akan coba disajikan dalam tulisan yang singkat dan sederhana ini. Dengan penelusuran pustaka, hasil studi menemukan bahwa ada beberapa pesan demokrasi yang sesuai dengan Islam, ada juga yang sebaliknya. Dalam Islam sendiri ada istilah yang hampir dekat dengan istilah demokrasi yakni shurā, akan tetapi keduanya ada perbedaan yang prinsip. Karena itu respon para sarjana Muslim pun beraneka ragam; ada yang menerima secara utuh istilah demokrasi, ada juga yang menentangnya, ada juga yang abu-abu - antara menentang dan menerima. Sedangkan dengan penerapan demokrasi di Indonesia, ternyata umat Islam Indonesia begitu menerima dan berhubungan positif dengan konsep demokrasi yang selama ini dianggap bertentangan dengan ajaran Islam oleh sebagian sarjana Islam.
\end{abstract}

Kata Kunci:

Islam; demokrasi; shurā; Indonesia

DOI: http://dx.doi.org/10.15575/jw.v39i1.583

Received: January 2015 ; Accepted: December 2015 ; Published: February 2016

\section{A. PENDAHULUAN}

Tema demokrasi adalah salah satu tema yang sampai saat ini masih menarik untuk didiskusikan. Berbagai karya yang mengulas tentang demokrasi telah dihasilkan-baik itu oleh para pemikir Islam maupun Barat. Semenjak kedatangan bangsa Barat ke dunia Islam, dan seiring dengan kemajuan bangsa Barat saat ini, maka sesuatu yang datang dari Barat selalu dijadikan indikator simbol kemajuan. Atas klaim itu sehingga banyak negara merasa penting untuk "mencontoh"baik secara langsung atau tidak-segala bentuk kemajuan yang pernah dicapai oleh Barat-termasuk di dalamnya tema demokrasi.

Di kalangan para intelektual Islam terdapat perbedaan pendapat dalam menanggapi permasalahan demokrasi. Apakah konsep yang mulanya warisan Barat ini dapat sesuai dengan Islam dan bisa diterapkan di negara Islam? Apakah arti demokrasi itu sendiri?. 
Permasalahan lainnya adalah apakah konsep demokrasi dengan shürā dalam Islam adalah sama? Untuk menjawab permasalahan ini, berbagai kalangan cendekiawan Muslim menyajikan konsepnya yang antara satu dengan lainnya saling berbeda pendapat. Itulah beberapa permasalahan yang akan dicoba dibedah dalam artikel ini.

\section{B. HASIL DAN PEMBAHASAN \\ 1. Pengertian Demokrasi}

Asal kata demokrasi adalah "demos", sebuah kosa kata Yunani berarti masyarakat, dan "kratio" atau "krato" yang dalam bahasa Yunani berarti pemerintahan. Demokrasi secara etimologis berarti "pemerintahan oleh rakyat" (rule by the people). Dilihat dari sejarahnya, pertama kali, istilah ini digunakan sekitar lima abad sebelum Masehi. Chleisthenes - tokoh pada masa itu-dianggap banyak memberi kontribusi dalam pengembangan demokrasi. Chleisthenes adalah tokoh pembaharu Athena yang menggagas sebuah sistem pemerintahan kota. Pada 508 SM, Chleisthenes membagi peran warga Athena ke dalam 10 kelompok. Setiap kelompok terdiri dari beberapa demes yang mengirimkan wakilnya ke Majelis yang terdiri dari 500 orang wakil.

Sejatinya, jauh sebelum bangsa Yunani mengenal demokrasi. Para ilmuwan meyakini, bangsa Sumeria yang tinggal di Mesopotamia juga telah mempraktikkan bentuk-bentuk demokrasi. Konon, masyarakat India Kuno pun telah menerapkan prinsip-prinsip demokrasi dalam kehidupan mereka, jauh sebelum Yunani dan Romawi.

"Demokrasi muncul dari pemikiran manusia," ungkap Aristoteles seorang pemikir termasyhur dari Yunani. Gagasan demokrasi yang berkembang di Yunani sempat hilang di barat, saat Romawi Barat takluk ke tangan suku Jerman. Pada abad pertengahan, Eropa Barat menganut sistem feodal. Kehidupan sosial dan spiritual dikuasai Paus dan pejabat agama Lawuja Magna Charta yang lahir pada 1215 dianggap sebagai jalan pembuka munculnya kembali demokrasi di Barat. Pada masa itu, muncullah pemikir-pemikir yang mendukung berkembangnya demokrasi seperti, John Locke dari Inggris (1632-1704) dan Montesquieu dari Prancis (1689-1755).

Demokrasi tumbuh begitu pesat ketika sampai masa renaissance, istilah ini digunakan untuk suatu sistem demokrasi langsung, yakni masyarakat secara langsung menempati posisi pemerintahan. Mereka berperan dalam seluruh aktivitas politik, legislatif, eksekutif, yudikatif dsb. Sejak dulu, sistem pemerintahan semacam ini ditentang oleh filsuf-filsuf besar. Plato menyifatinya sebagai pemerintahan orang-orang bodoh. Aristoteles menamakannya pemerintahan orang-orang miskin tak berkeutamaan. Abu Nasr Al-Farabi dan Ibn Rusyd menyebutnya sebagai kebusukan dalam pemerintahan utama (madinah fadiliah).

Salah satu keberatan lain yang cukup kasat mata adalah bahwa sistem ini sama sekali tidak praktis apabila jumlah masyarakat telah membesar. Oleh karena itu, Jean Jacques Rousseau beserta filsuf politik lain menyempurnakannya dengan teori demokrasi perwakilan, sistem pemilihan para wakil rakyat sebagai pemerintah. Sistem perwakilan ini telah menjadi norma berharga dan prinsip yang diterima di dunia sehingga memaksa banyak cendekiawan muslim menciptakan teori demokratisasi Islam.

Demokrasi adalah suatu bentuk pemerintahan di mana kekuasaan tertinggi berada di tangan rakyat, dilaksanakan secara langsung oleh mereka, atau oleh wakil terpilih dalam sistem pemilu yang bebas. ${ }^{1}$ Karena definisi ini maka Abraham Lincoln, salah seorang mantan Presiden Amerika Serikat, mengatakan bahwa dalam proses demokrasi mengharuskan adanya partisipasi rakyat dalam memutuskan suatu permasalahan dan mengontrol pemerintahan yang berkuasa. ${ }^{2}$

Sedangkan Sadek J. Sulaiman ${ }^{3}$ mengatakan bahwa prinsip dasar demokrasi adalah adanya

\footnotetext{
${ }^{1}$ Ali Nawaz Memon, "Membincang Demokrasi," dalam Islam Liberalisme Demokrasi, terj. Mun'im A. Sirry (Jakarta: Paramadina, 2002), 3.

${ }^{2}$ Sadek J. Sulaiman, "Demokrasi dan Shura," dalam Islam Liberal, ed. Charles Khurzman, terj. Bahrul Ulum dan Heri Junaedi (Jakarta: Paramadina, 2003), 125.

${ }^{3}$ Ia adalah seorang mantan duta besar Oman untuk Amerika Serikat.
} 
kesamaan antara seluruh manusia. Apa pun bentuk diskriminasi manusia, baik yang berdasarkan ras, gender, agama, status sosial, adalah bertentangan dengan demokrasi. ${ }^{4}$ Lebih lanjut ia mengatakan dalam demokrasi ada tujuh prinsip: Pertama, kebebasan berbicara. Dalam sistem ini setiap warga negara bebas untuk mengemukakan pendapatnya tanpa harus merasa takut. Dalam sistem demokrasi, hal ini sangat penting untuk mengontrol kekuasaan agar berjalan dengan benar. Kedua, pelaksanaan pemilu. Pemilu ini merupakan sarana konstitusional untuk melihat dan menilai apakah pemerintah yang berkuasa layak didukung kembali atau perlu diganti dengan yang lain. Ketiga, kekuasaan dipegang oleh mayoritas tanpa mengabaikan kontrol minoritas. Prinsip ini mengakui adanya hak oposisi suatu kelompok terhadap pemerintah. Keempat, sejalan dengan prinsip ketiga, dalam sistem demokrasi, partai politik memainkan peranan penting, rakyat berhak dengan bebas mendukung partai mana yang lebih sesuai dengan pandangan dan pilihannya. Kelima, demokrasi meniscayakan pemisahan antara kekuasaan legislatif, eksekutif, dan yudikatif. Dengan pemisahan ini akan ada checks and balances, sehingga kekuasaan akan terhindar dari praktik-praktik eksploitatif. Keenam, demokrasi menekankan adanya supremasi hukum. Semua individu harus tunduk di bawah hukum, tanpa memandang kedudukan dan status sosialnya. Ketujuh, dalam demokrasi, semua individu atau kelompok bebas melakukan perbuatan. Karenanya semua individu bebas mempunyai hak milik, tanpa boleh diganggu oleh pihak manapun.

\section{Antara Demokrasi dan Shürā}

Menanggapi permasalahan di atas, kalangan intelektual Muslim saling berbeda pendapat. Sebagian dari mereka memandang demokrasi dan shürā adalah dua hal yang identik; sebagian yang lain memandang berbeda yakni demokrasi dan shürāadalah dua hal yang saling berlawanan. Sebagian lagi dengan maksud mendamaikan dua kubu yang

\footnotetext{
${ }^{4}$ Sulaiman, "Demokrasi dan Shura.”, 125.
}

berlawanan di atas berpendapat bahwa antara demokrasi dan shüra dalah dua istilah yang mempunyai sisi persamaan, dan tak sedikit juga sisi perbedaannya dengan Islam.

Hasil Kongres Amerika pada tahun 1989, memutuskan beberapa kriteria sebuah negara bisa dikatakan demokratis bila; Pertama, didirikan sistem politik yang sepenuhnya demokratis dan representatif berdasarkan pemilihan umum yang bebas dan adil; Kedua, diakui secara efektif kebebasan-kebebasan fundamental dan kemerdekaan-kemerdekaan pribadi, termasuk kebebasan beragama, berbicara dan berkumpul; Ketiga, dihilangkan semua perundang-undangan dan peraturan yang menghalangi berfungsinya pers yang bebas dan terbentuknya partai-partai politik; Keempat, diciptakan suatu badan kehakiman yang bebas; dan Kelima, didirikan kekuatankekuatan militer, keamanan, dan kepolisian yang tidak memihak. ${ }^{5}$ Kriteria yang tidak jauh berbeda juga diungkapkan oleh Franz Magnis Suseno dan Afan Ghafar. Menurut Franz Magnis Suseno, sebuah negara demokrasi apabila ia memiliki; 1).Negara hukum; 2). Pemerintahan yang berada di bawah kontrol nyata masyarakat; 3).Ada pemilihan umum berkala yang bebas; 4). Prinsip mayoritas; dan 5).Adanya jaminan terhadap hak-hak demokratis dasar. ${ }^{6}$ Sedangkan menurut Afan Ghafar hampir sama dengan Franz Magnis dengan tanpa menyebutkan hukum.

Dari beberapa prinsip di atas, sepintas terlihat bahwa konsep demokrasi sesuai dengan apa yang diajarkan dalam Alquran tentang shürā, tetapi apakah benar kedua istilah ini sama, baik itu dalam konsep maupun aplikasinya. Dalam bagian

\footnotetext{
${ }^{5}$ Sukron Kamil, Islam dan Demokrasi; Telaah Konseptual dan Historis (Jakarta: Gaya Media Pratama, 2002), 32.

${ }^{6}$ Franz Magnis-Suseno, "Demokrasi Tantangan Universal," dalam Agama dan Dialog Antar Peradaban, ed. M. Nasir Tamara dan Elza Peldi Taher (Jakarta: Paramadina, 1996), 127.

${ }^{7}$ Afan Ghafar, "Demokratisasi dan Prospeknya di Indonesia Orde Baru," dalam pengantar Buku Demokratisasi Politik, Budaya dan Ekonomi; Pengalaman Indonesia Masa Orde Baru, ed. Elza Peldi Taher (Jakarta: Paramadina, 1994), xxvii-xxix.
} 
selanjutnya akan diuraikan kajian kritis tentang konsep demokrasi dan shürä.

Demokrasi selalu muncul sebagai isu sentral dalam setiap episode sejarah peradaban manusia dan merupakan satu-satunya isu dan wacana yang mampu menyatukan cita ideal manusia sejagad karena wacana demokrasi mampu melintasi batas-batas geografis, suku bangsa, agama, dan kebudayaan. Menanggapi permasalahan ini, kalangan intelektual Muslim saling berbeda pendapat. Mengutip klasifikasi yang dilakukan oleh John L. Esposito dan James P. Piscatori, tanggapan para cendekiawan Muslim terhadap demokrasi bisa diklasifikasikan menjadi tiga kelompok; ${ }^{8}$

Pertama, sebagian dari mereka memandang demokrasi dan shürā adalah dua hal yang identik akan tetapi terdapat juga perbedaan. Di antara cendekiawan Muslim yang beranggapan seperti adalah Imam Khomeini. Ia mengatakan bahwa di satu sisi Iran menganggap bahwa Tuhan sebagai penguasa mutlak yang semua perintah-Nya harus diikuti, sedangkan di sisi lain sebagai negara republik, Iran memandang perlunya partisipasi rakyat di bidang politik, ekonomi, sosial, dan budaya, seperti lewat pemilu untuk memilih wakil mereka di parlemen, pemilu presiden. Pemerintah Iran merupakan pemerintahan hukum Tuhan atas manusia sebagai pemegang kedaulatan tertinggi, tetapi juga dengan parlemen yang bertugas menyusun program untuk berbagai kementerian, dengan kekuasaan tertinggi di tangan seorang faqih. ${ }^{9}$ Cendekiawan Muslim lainnya yang masuk dalam kelompok ini adalah Taufiq al-Syawi dalam bukunya "Fiqh al- Shürā wa al-Istisharah" ia mengatakan bahwa demokrasi merupakan bentuk shürä versi Eropa. Meskipun begitu, demokrasi tidak sama dengan shürā karena tidak berpegang pada dasar syariat Islam. Menurutnya,

\footnotetext{
${ }^{8}$ John L. Esposito dan James P. Piscatori, "Islam dan Demokrasi," Islamika, Jurnal Dialog Pemikiran Islam April-Januari, no. 4 (1994), 19-21.

${ }^{9}$ Riza Sihbudi, "Masalah Demokratisasi di Timur Tengah," dalam Agama, Demokrasi, dan keadilan, terj. M. Imam Aziz (Jakarta: Gramedia, 1993), 174. atau lihat Riza Sihbudi, "Bahasa dalam Kelompok Syi'ah, Kasus Vilayat Faqih," Islamika, Jurnal Dialog Pemikiran Islam, no. 5 (1994), 47-48.
}

demokrasi konvensional sangat rentan terhadap prilaku diktator, karena demokrasi memungkinkan penguasa melakukan upaya tertentu merebut dan mempengaruhi kekuasaan legislatif, lalu menciptakan undangundang tersendiri yang berfungsi untuk memperluas kekuasaannya. Dengan begitu ia menegaskan bahwa sistem shürā sebenarnya telah melangkah lebih maju ketimbang sistem demokrasi modern, karena sistem shürä mewajibkan para penguasa berpegang pada syariat atau sumber samawi yang lebih tinggi dari penguasa yang tidak memungkinkan mereka mencampurinya, sekalipun pada persoalan yang tidak dijelaskan secara pasti, karena itu wewenang ulama. ${ }^{10}$

Kedua, sebagian yang lain memandang berbeda yakni shürā dan demokrasi adalah dua hal yang saling berlawanan dan harus ditolak. Di antara cendekiawan Muslim yang masuk dalam katagori ini adalah Syaikh Fadhallah Nuri, Sayyid Qutub, al-Sya'rawi, Ali Benhadji, Hasan Turabi, Abū al-A'lâ alMaudūdi.

Menurut Syaikh Fadhallah Nuri, demokrasi adalah persamaan semua warga negara, dan hal ini menurutnya sangatlah tidak mungkin dalam Islam. Dalam demokrasi, perbedaan yang luar biasa yang tidak mungkin dihindari pasti terjadi. Misalnya; antara yang beriman dan yang tidak beriman, antara yang kaya dan miskin, antara faqih (ahli hukum) dan penganutnya. Tidak hanya itu, ia juga menolak legislasi oleh manusia. Agama Islam menurutnya tidak memiliki kekurangan yang memerlukan penyempurnaan dan dalam Islam tidak ada seorang pun yang diizinkan mengatur hukum. Karena itu, ia menegaskan bahwa demokrasi sangatlah bertentanga dalam Islam. ${ }^{11}$ Nada mengecam terhadap demokrasi juga disampaikan oleh Sayyid Qutub, ia mengatakan bahwa demokrasi adalah sebuah pelanggaran terhadap kekuasaan Tuhan dan merupakan suatu bentuk tirani sebagian orang

\footnotetext{
${ }^{10}$ Taufiq Al-Syawi, Syura Bukan Demokrasi, terj. Djamaluddin ZS (Jakarta: Gema Insani Press, 1997), 21-23.

${ }^{11}$ John L. Esposito, Islam dan Politik (Jakarta: Bulan Bintang, 1990), 118.
} 
kepada yang lainya. Menurutnya mengakui kekuasaan Tuhan berarti melakukan penentangan secara menyeluruh terhadap kekuasaan manusia dalam seluruh pengertian, bentuk, sistem dan kondisi. Ia menambahkan bahwa agresi menentang kekuasaan Tuhan adalah bentuk jahiliyah. Ia menandaskan bahwa negara Islam harus berlandaskan pada prinsip musyawarah, karena Islam sebagai sebuah sistem hukum dan moral sudah lengkap, sehingga dengan demikian tidak ada lagi legislasi lain yang mengatasinya. Pendapat serupa pula dikatakan oleh Mutawali alSya'rawi seorang ulama besar asal Mesir yang mengatakan bahwa Islam dan demokrasi tidak bersesuaian, dan shürā tidak dengan sendirinya demokrasi mayoritas. ${ }^{12}$ Ali Benhadji seorang pemimpin FIS (Front Islamique du Salut) mengatakan bahwa konsep demokrasi adalah sebuah konsep Yudeo-Kristen yang harus diganti dengan prinsip-prinsip kepemimpinan yang inhern dalam Islam. Para teotitisi politik Barat sendiri, kata Benhadji mulai melihat sistem demokrasi adalah sistem yang cacat. Menurutnya demokrasi hanya dinilai baik jika lebih menguntungkan Barat daripada negara Islam itu sendiri. ${ }^{13}$ Menurut John L. Esposito dan James P. Piscatori bahwa sebagian umat Muslim mencemaskan model demokrasi Barat serta sistem pemerintahan yang dicanangkan Inggris. Sebenarnya, reaksi negatif tersebut merupakan ungkapan dari penolakan secara redikal terhadap kolonialisme Eropa, dan merupakan pembelaan terhadap Islam dalam usaha mengurangi ketergantungan umat Islam terhadap negara-negara Barat. Ungkapan penolakan terhadap kolonialisme Eropa tadi berakibat pada penolakan terhadap sistem demokrasi Barat. ${ }^{14}$

Ketiga, sebagian lagi dengan maksud mendamaikan dua kubu yang berlawanan di

\footnotetext{
${ }^{12}$ Kamil, Islam dan Demokrasi; Telaah Konseptual dan Historis, 48.

${ }^{13}$ John L. Esposito dan John O. Voll, Demokrasi di Negara-Negara Muslim (Bandung: Mizan, 1999), 214.

${ }^{14}$ John L. Esposito dan James P. Piscatori, "Islam and Democracy," Middle East Journal VL, no. III (1991). Atau lihat Fahmi Huwaydi, Al-Islām wa alDemuqrätỉyah (Kairo: Markaz al-Ahram, 1993).
}

atas berpendapat bahwa antara shürā dan demokrasi adalah dua istilah yang mempunyai sisi persamaan. Di antara para cendekiawan yang masuk dalam kelompok ini adalah Muhammad Husein Heikal, Fahmi Huwaidi, Mohammad Taha, Abdullah Ahmad al-Na'im, Bani Sadr, Mehdi Bazargan, Hasan al-Hakim, Amin Rais.

Menurut Fahmi Huwaidi, demokrasi adalah sangat dekat dengan Islam dan substansinya sejalan dengan Islam. Argumentasi yag dihadirkan oleh Fahmi Huwaidi adalah; Pertama, beberapa hadits menunjukan bahwa Islam menghendaki pemerintahan yang disetujui oleh rakyatnya. Kedua, penolakan Islam kepada kediktatoran. Ketiga, dalam Islam, pemilu merupakan kesaksian rakyat dewasa bagi kelayakan seorang kandidat dan mereka tentu saja seperti yang diperintahkan Alquran. Keempat, demokrasi merupakan se-buah upaya mengembalikan sistem kekhila-fahan Khulafa al-Rashidin yang memberikan hak kebebasan kepada rakyat yang hilang ketika beralihnya sistem kekuasaan Islam kepada sistem kerajaan. Kelima, negara Islam adalah negara keadilan dan persamaan ma-nusia di depan hukum. Kelima, suara mayoritas tidaklah identik dengan kesesatan, kekufuran dan ketidaksyukuran. Keenam, legislasi dalam parlemen tidaklah berarti penentangan terhadap legislasi ketuhanan. ${ }^{15}$

Muhammad Husein Heikal berpendapat bahwa kebebasan, persaudaraan, dan persamaan yang merupakan semboyan demokrasi dewasa ini juga termasuk di antara prinsipprinsip utama Islam. Kaidah-kaidah yang ditetapkan oleh paham demokrasi sekarang sebenarnya juga merupakan kaidah-kaidah Islam. ${ }^{16}$ Mohammad Taha salah seorang pemikir Sudan mengatakan bahwa demokrasi sejajar dengan sosialisme. Keduanya adalah dua sayap masyarakat yang dibutuhkan. Sosialisme merupakan proses mencari kemak-

\footnotetext{
${ }^{15}$ Fahmi Huwaidi, Demokrasi, Oposisi, dan Masyarakat Madani, terj. M. Abdul Ghofar (Bandung: Mizan, 1996), 193.

${ }^{16}$ Muhammad Husein Heikal, Pemerintahan Islam, terj. Tim Pustaka Firdaus (Jakarta: Pustaka Firdaus, 1993), 95.
} 
muran sosial yang lebih baik, maka demokrasi merupakan proses pembagian kekuasaan yang mesti mendahuluinya. Menurut Taha, demokrasi bukan akhir dari sebuah tujuan, tetapi sebagai sarana untuk meraih tujuan merealisasikan martabat manusia. Demokrasi tidak hanya pandangan dari suatu pemerintahan, tetapi juga pandangan hidup, dan demokrasi merupakan pendekatan terbaik bagi usaha pencapaian martabat manusia. Taha menyadari bahwa dalam demokrasi banyak ketidaksempurnaan, meskipun begitu menurutnya ketidaksempurnaannya lebih rendah dibandingkan dengan marxisme. Ia menambahkan bahwa demokrasi adalah kebalikan dari kediktatoran di mana ia merupakan tipe pemerintahan yang memiliki kemampuan tinggi dalam menyediakan kesempatan bagi manusia untuk merealisasikan kehormatan dan kemuliaannya. Yang menarik dari pemikiran Taha adalah ia mela-kukan kritik terhadap konsep shürā yang menurutnya shürā bukanlah ajaran asli Islam tetapi cenderung sebagai sebuah ajaran subsider. Menurutnya musyawarah bukanlah demokrasi, tetapi lebih sebagai aturan di mana individu-individu dewasa menyiapkan negara menuju demokrasi. Dengan tegas ia menyatakan justru demokrasi adalah merupakan konsep asli Islam. ${ }^{17}$ Pandangan apresiatif terhadap demokrasi juga datang dari seorang mantan presiden pertama Iran masa Imam Khomeini yakni Bani Sadr. Ia mengatakan bahwa konsep wilayatul Faqih Imam khomeini yang diterapkan di Iran hingga sekarang telah memberikan peranan yang terlalu besar kepada ulama dalam urusan kenegaraan, mereka menguasai lembaga perwalian yang memiliki hak veto. Dengan hak seperti itu, maka akibatnya kekuasaan sulit dikontrol dan tingkat partisipasi politik rakyat menjadi sangat rendah, padahal dalam sistem demokrasi, kontrol terhadap kekuasaan dan adanya partisipasi politik rakyat merupakan dua unsur yang sangat dominan. Pendapat senada pun diungkapkan oleh politisi Iran lainnya yakni Mehdi Bazargan yang mengatakan bahwa

\footnotetext{
${ }^{17}$ Kamil, Islam dan Demokrasi; Telaah Konseptual dan Historis, 61.
}

demokrasi sebagai kebenaran universal yang tidak perlu dipersoalkan. ${ }^{18}$

Pembelaan terhadap konsep demokrasi juga datang dari Amin Rais yang merupakan salah seorang cendekiawan Indonesia, bahwa ia tidak melihat adanya pertentangan antara Islam (musyawarah) dengan demokrasi. Hanya saja menurutnya istilah demokrasi dewasa ini telah disalahpahami menurut kepentingan politik rezim yang berkuasa. Lebih lanjut ia mengutarakan tiga alasan penerimaannya terhadap konsep demokrasi; pertama, secara konsep dasar, Alquran memerintahkan umat Islam agar melaksanakan musyawarah dalam menyelesaikan masalahmasalah mereka. Kedua, secara historis, Nabi mempraktekkan musyawarah dengan para sahabat. Ketiga, secara rasional, umat Islam diperintahkan untuk menyelesaikan dilema dan masalah-masalah mereka.

Salah seorang ulama yang mempunyai pendapat seperti yang terakhir di atas adalah Yusuf Al-Qardhawy, ia mengatakan bahwa secara substansi, demokrasi tidak bertentangan dengan Islam, bahkan ajaran substansi demokrasi telah lama dikenal oleh Islam. ${ }^{19}$ Meskipun substansi demokrasi sudah dikenal oleh Islam, akan tetapi rinciannya diserahkan kepada ijtihad orang-orang Muslim, sesuai dengan dasar-dasar agamanya, kemaslahatan dunianya, perkembangan hidupnya menurut pertimbangan tempat dan waktu serta trend kehidupan manusia. Lantas pertanyaannya adalah apakah substansi dari demokrasi itu sendiri?. Ia menjawab bahwa substansi demokrasi terlepas dari berbagai definisi istilah-istilah akademis adalah suatu proses pemilihan yang melibatkan banyak orang untuk mengangkat seseorang yang berhak memimpin dan mengurus keadaan mereka. Dan hal ini tentu saja mereka tidak akan mengangkat seseorang yang tidak mereka sukai atau sistem yang mereka benci. Mereka berhak memperhitungkan pemimpin yang

\footnotetext{
${ }^{18}$ Dawam Rahardjo, “Syura,” Jurnal Ulumul Qur'an 1, no. 1 (1989), 34

${ }^{19}$ Yusuf Al-Qardhawy, Fiqih Daulah; Dalam Perspektif Al-Qur'an dan Sunnah, terj. Kathur Suhardi (Jakarta: Pustaka al-Kautsar, 1997), 184
} 
melakukan kesalahan, berhak mencopot dan menggantinya dengan orang lain jika menyimpang. ${ }^{20}$ Alasan lain diterimanya konsep demokrasi dalam Islam menurutnya karena demokrasi mempunyai beberapa kelebihan, di antaranya adalah demokrasi telah menuntun ke beberapa bentuk dan sarana, yang hingga kini dianggap sebagai satu-satunya sistem yang memberi jaminan keselamatan bagi rakyat dari jarahan tangan para tiran. Meskipun begitu, sistem demokrasi juga tak bisa dilepaskan dari kecacatan dan kekurangan, seperti lazimnya perbuatan manusia yang tak lepas dari kekurangan. Ia menganjurkan bahwa tidak ada salahnya bagi kita untuk mencari alternatif sistem lain yang lebih ideal dan lebih baik, tapi harus lebih mudah diterapkan dalam kehidupan manusia. Karena itu, tak ada salahnya bagi kita untuk mengambil sistem demokrasi, sebagai sarana untuk mewujudkan keadilan dan shüra, menghormati hak-hak manusia, menghadang langkah para tiran di muka bumi ini. ${ }^{21}$ Yang menarik dari pemikiran Yusuf Al-Qardhawy ini di dalam memperkuat argumentasinya adalah dengan memakai kaidah hukum "Apabila yang wajib tidak bisa mencapai sempurna kecuali dengan sesuatu, maka sesuatu itu pun hukumnya wajib". Dari sinilah kita bisa mengambil tatacara demokrasi dan kandungan-kandungannya yang sesuai dengan diri kita dan kita bisa menyaring dan membenahinya.

Jika kita bandingkan pendapat Yusuf AlQardhawy di atas dengan pendapat Taqiyuddin Al-Nabhani sangatlah bertolak belakang. Taqiyuddin Al-Nabhani mengatakan jika suatu istilah asing mempunyai makna yang bertentangan dengan Islam, istilah itu tidak boleh digunakan. Sebaliknya, jika maknanya terdapat dalam khazanah pemikiran Islam, istilah tersebut boleh digunakan. Dalam hal ini menurutnya Islam telah melarang umatnya untuk menggunakan istilah-istilah yang menimbulkan kerancuan, apalagi

\footnotetext{
${ }^{20}$ Al-Qardhawy, Fiqih Daulah; Dalam Perspektif AlQur'an dan Sunnah, 183.

${ }^{21}$ Al-Qardhawy, Fiqih Daulah; Dalam Perspektif AlQur'an dan Sunnah, 192-193.
}

kerancuan yang menghasilkan pengertianpengertian yang bertolak belakang antara pengertian yang Islami dan yang tidak Islami. $^{22}$ Pernyataan senada pun dikumandangkan oleh Ihsan Sammarah dalam kitabnya Mafhüm Al-'Adalah Al-Ijtima'iyah fí AlFikri Al-Islāmì Al-Mu'așir yang menyatakan penolakannya atas penggunaan istilah yang dapat menimbulkan kerancuan atau bias, yang pengertiannya kemungkinan berupa makna Islami atau makna yang tidak Islami. Karena itu, penggunaan istilah demokrasi, teokrasi, atau teo-demokrasi tidak dapat diterima, karena pengertiannya mengandung ambivalensi antara yang mengartikannya menurut perspektif sekular dan yang mengartikannya menurut perspektif Islami. ${ }^{23}$ Membandingkan dua pendapat di atas yang bertolak belakang, nampaknya keduanya di dalam memandang demokrasi berawal dari persepsi yang berbeda. Yusuf Al-Qardhawy memahami demokrasi dari sisi substansi yang dibawa oleh demokrasi itu sendiri. Sedangkan Taqiyuddin Al-Nabhani dan Ihsan Sammarah memandang demokrasi bukan dari pesan yang dibawanya melainkan dari sejarah kemunculan istilah itu sendiri yakni dari Barat yang tentunya berbeda dengan Islam.

Membicarakan tentang apakah konsep demokrasi sesuai atau malah bertentangan dengan Islam memang tidak mudah. Karena bagaimanapun, konsep ini bermula dari Barat yang tentunya mempunyai latar belakang alasan kemunculannya tersendiri. Meskipun begitu, tidak sedikit para ilmuwan Islam yang memandang bahwa konsep demokrasi sesuai dengan konsep Islam. Berbagai istilah yang dikenal dalam Islam kerapkali disamasamakan atau disepadankan dengan pengertian demokrasi, seperti keadilan (' $a d l$ ), persamaan (musāwah), musyawarah (shürāa). Meskipun begitu, tidak sedikit ilmuwan Muslim menolak penyamaan antara demokrasi dengan beberapa istilah di atas dengan alasan bahwa Muslim

\footnotetext{
${ }^{22}$ Taqiyuddin Al-Nabhại, Niẓam Al-Islām, (t.tp.: t.p., 2001), 85-86.

${ }^{23}$ Iḥsān Sammarah, Mafhūm Al-'Adālah AlIjtimaiyah fì Al-Fikri Al-Islāmī Al-Mu'așir (Bairut: Dār Al-Nahdah Al-Islāmiyah, 1991), 10-11.
} 
tidak dibolehkan untuk menciptakan kesepakatan-kesepakatan yang dinegosiasikan terhadap segala sesuatu yang dipercaya bertentangan dengan hukum Allah dan hal ini berbeda dengan demokrasi, apapun boleh dinegosiasikan. Melihat dari kenyataan di atas, maka alangkah baiknya jika kita sedikit berhati-hati ketika membicarakan kaitan antara demokrasi dengan Islam. Untuk memperjelas uraian dua istilah di atas, penulis terlebih dahulu menguraikan istilah shürā dalam Alquran.

Kata shürā yang berasal dari kata kerja "shawara-yushawiru" secara etimologis berarti menjelaskan, menyatakan atau mengajukan dan mengambil sesuatu. Bentuk lain yang berasal dari kata kerja "shawara" adalah ashara (memberi isyarat), "tashawara" (berunding, saling bertukar pendapat), "shawir" (meminta pendapat), dan "mustashir" (meminta pendapat orang lain). Dari istilah-istilah di atas dapat dimengerti bahwa shürā adalah saling menjelaskan dan merundingkan pendapat atau saling meminta dan menukar pendapat mengenai suatu perkara.

Jika merujuk pada definisi istilah yang tertera dalam kamus "Lisān al- 'Arab" maka kata shürā yang berasal dari kata "sha-w-r" secara etimilogis berarti mengeluarkan madu dari sarang lebah. ${ }^{24}$ Dari definisi ini, Quraish Shihab memberikann definisi shürā dengan segala sesuatu yang dapat diambil atau dikeluarkan dari yang lain untuk memperoleh kebaikan. Menurutnya hal tersebut semakna dengan pengertian lebah yang mengeluarkan madu yang berguna bagi manusia. ${ }^{25}$

Istilah shürā sendiri sebenarnya sudah dikenal dan dipraktekkan bangsa Arab pada masa pra-Islam. Sebagaimana dikatakan oleh Fazlur Rahman bahwa shürā merupakan tuntutan abadi dari kodrat manusia sebagai makhluk sosial. Hanya saja Alquran merubah shürā dari sebuah institusi suku yang berlandaskan pada hubungan darah menjadi institusi komunitas yang menekankan prinsip

\footnotetext{
${ }^{24}$ Ibn Manzūr, Lisānul 'Arab, Jilid 4 (Beirut: Dār alShadr, 1968), 434.

${ }^{25}$ Muhammad Quraish Shihab, Wawasan Al-Qur'an (Bandung: Mizan, 1996), 469.
}

hubungan iman. ${ }^{26}$ Tesis Fazlur Rahman ini mendapatkan argumentasi pembenaran jika merujuk ungkapan Muhammad Yusuf Musa yang mengatakan bahwa masyarakat Arab (pemuka Arab) kalau mereka tidak diajak untuk bermusyawarah dalam urusan mereka, mereka akan kecewa dan berkecil hati. Hal ini semata-mata dilakukan dalam rangka mempererat hungan darah dengan mereka dan menghilangkan rasa kecewa di kalangan mereka. $^{27}$

Jika merujuk pada penjelasan Alquran, maka kata shürā dapat dijumpai dalam tiga ayat. Pertama:

Para ibu hendaklah menyusukan anakanaknya selama dua tahun penuh, yaitu bagi yang ingin menyempurnakan penyusuan. Dan kewajiban ayah memberi makan dan pakaian kepada para ibu dengan cara yang ma`ruf. Seseorang tidak dibebani melainkan menurut kadar kesanggupannya. Janganlah seorang ibu menderita kesengsaraan karena anaknya dan juga seorang ayah karena anaknya, dan warispun berkewajiban demikian. Apabila keduanya ingin menyapih (sebelum dua tahun) dengan kerelaan keduanya dan permusyawaratan, maka tidak ada dosa atas keduanya. Dan jika kamu ingin anakmu disusukan oleh orang lain, maka tidak ada dosa bagimu apabila kamu memberikann pembayaran menurut yang patut. Bertakwalah kepada Allah dan ketahuilah bahwa Allah Maha Melihat apa yang kamu kerjakan.” (QS: alBaqarah: 233)

Dalam ayat ini diuraikan bagaimana antara suami dan istri diharuskan untuk bermusyawarah ketika mengambil keputusan yang berkaitan dengan rumah tangga dan anak-anak termasuk di dalamnya menyapih anaknya sebelum berumur dua tahun. Kedua:

Maka disebabkan rahmat dari Allah-lah kamu berlaku lemah-lembut terhadap mereka. Sekiranya kamu bersikap keras lagi berhati kasar, tentulah mereka men-

\footnotetext{
${ }^{26}$ Muhammad Syafi'i Maarif, Islam dan Masalah Kenegaraan (Jakarta: LP3ES, 1985), 49-50.

${ }^{27}$ Muhammad Yusuf Musa, Nizām al-Hukm fí alIslām (Kairo: Dār al-Katib al-'Arabì, t.t.).
} 
jauhkan diri dari sekelilingmu. Karena itu ma'afkanlah mereka, mohonkanlah ampun bagi mereka, dan bermusyawarahlah dengan mereka dalam urusan itu. Kemudian apabila kamu telah membulatkan tekad, maka bertawakkallah kepada Allah. Sesungguhnya Allah menyukai orang-orang yang bertawakkal kepada-Nya. (QS: Ali-'Imran: 159)

Asbāb al-nuzūl ayat ini ketika terjadi perang Uhud yang membawa kekalahan bagi umat Islam, pada waktu itu, Nabi sendiri mengalami luka-luka. Atas kejadian itu, maka turunlah ayat ini dalam rangka memberi pelajaran kepada Nabi dan seluruh umat Islam agar selalu melakukan musyawarah dalam memutuskan sesuatu yang bersangkutan bagi kemaslahatan umat. Ketiga:

Dan (bagi) orang-orang yang menerima (mematuhi) seruan Tuhannya dan mendirikan shalat, sedang urusan mereka (diputuskan) dengan musyawarah antara mereka; dan mereka menafkahkan sebagian dari rezki yang Kami berikan kepada mereka. (QS: al-Shūra 42: 38)

Ayat ini Allah memberikann uraian tentang salah satu ciri seorang mukmin yaitu mendirikan sholat dengan baik dan benar, menafkahkan rizki dengan amanah dan ia selalu bermusyawarah sebelum mengambil keputusan.

Ketiga ayat di atas menjelaskan bahwa Islam sangat menganjurkan umat Islam untuk selalu mengedepankan musyawarah terlebih dahulu sebelum memutuskan sebuah perkara. Terbukti dengan dimasukkannya musyawarah sebagai ciri orang yang beriman sebagaimana dalam surat al-Shura ayat 38 di atas.

Meskipun Alquran sangat mementingkan musyawarah, akan tetapi Allâh tidak menguraikan bagaimana prosedur, bentuk atau tata cara bermusyawarah. Hal ini secara tidak langsung memberikan gambaran kepada manusia bahwa Alquran bukanlah seperti karya ilmiah lainnya yang harus ditulis dan diuraikan dengan sangat mendetail agar tidak terjadi kesalahan pemahaman. Alquran adalah kitab suci petunjuk umat Islam yang bersifat global. Keglobalan tersebut memberikan kesempatan kepada manusia untuk memikirkan bagaimana prosedur dan mekanisme penyelesaiannya yang sesuai dengan kebutuhannya termasuk di dalamnya masalah shüra. Penafsiran lain mengapa Alquran tidak memberikan penjelasan secara mendetail tentang shüra karena Alquran ternyata menganut prinsip bahwa untuk permasalahanpermasalahan yang sifatnya bisa berkembang sesuai dengan kondisi, budaya, politik, dan ekonomi, maka Alquran tidak menguraikannya secara final, akan tetapi hanya menetapkan garis-garis besarnya saja. Langkah ini bertujuan memberikan kesempatan kepada manusia untuk memikirkan penyelesaiannya secara baik dan sesuai dengan kebutuhannya sejauh tidak melanggar atau bertentangan dengan ketentuan yang jelas dilarang dalam Alquran. Sebagaimana sabda Rasulullah Saw yang diriwayatkan oleh Imam Muslim: "Kalian lebih mengetahui persoalan dunia kalian", atau sabda Rasulullah Saw yang diriwayatkan oleh Ahmad: "Yang berkaitan dengan urusan agama kalian, maka kepadaku (rujukannya), dan yang berkaitan dengan urusan dunia kalian, maka kalian lebih mengetahui".

Uraian di atas memunculkan permasalahan dalam hal apa sajakah yang harus dimusyawarahkan sebelum mengambil keputusan? Dalam menjawab permasalahan ini para ulama berbeda pendapat. Sebagian di antara mereka seperti Muqatil, Ibn Abi Rabi' mengatakan bahwa permasalahan-permasalahan yang harus dimusyawarahkan hanyalah yang berkaitan dengan strategi berperang sesuai dengan penjelasan surat Ali Imran ayat 159 di atas. $^{28}$ Kelompok ini nampaknya menafsirkan ayat di atas secara literalis atau harfiah sehingga kejadian atau asbāb al-nuzūl ayat di atas menjadi patokan bahwa permasalahan yang dibolehkan untuk dimusyawarahkan hanya berkaitan dengan strategi berperang saja tidak pada yang lain.

Berbeda dengan pendapat-pendapat ulama di atas, ulama lain seperti Hasan Basri, alDahaq mengatakan bahwa permasalahan-

\footnotetext{
${ }^{28}$ Musa, Nizām al-Hukm fí al-Isläm.
} 
permasalahan yang harus dimusyawarahkan hanya khusus terkait pada masalah yang berkaitan dengan urusan duniawi saja bukan dalam permasalahan agama. Alasan mereka adalah bahwa sebenarnya Nabi tidaklah membutuhkan jawaban-jawaban dari sahabatnya, akan tetapi bermaksud mendidik umatnya betapa musyawarah ini merupakan hal yang sangat penting dalam kehidupan sosial politik umat Islam. $^{29}$ Pendapat lain, pendapat ulama-ulama modern, yang mengatakan bahwa musyawarah tidaklah dilakukan hanya untuk permasalahan duniawi saja, akan tetapi juga untuk permasalahan keagamaan. Untuk itulah menurut kelompok ini, musyawarah dalam segi apa pun harus dilakukan baik urusan duniawi maupun agama. Kemajuan teknologi, agama pun akan terkena imbas dan tentunya membutuhkan solusi yang tidak bisa ditunda-tunda. Dari ketiga pendapat di atas, tampaknya pendapat yang lebih masuk akal dan realistis adalah pendapat yang terakhir, yang mengemukakan argumentasi jika perkembangan dan perubahan masyarakat tidak di antisipasi untuk diberikan solusinya secara bersama-sama, maka tidak tertutup kemungkinan umat Islam dengan tidak membutuhkan waktu yang lama akan tertinggal jauh.

Konsep di atas jika dibandingkan dengan pengertian teori demokrasi sebagaimana yang sudah dijelaskan sebelumnya bahwa dalam demokrasi apa pun boleh dinegosiasikan; dalam demokrasi, semua individu atau kelompok bebas melakukan perbuatan, maka kelompok yang ketiga di atas secara otomatis menerima dan menganggap bahwa pesan-pesan demokrasi sesuai dengan Islam.

Meskipun begitu, menurut hemat penulis, bagaimanapun tidak semua permasalahan agama harus dimusyawarahkan. Ada beberapa hal yang tidak layak atau dilarang untuk dimusyawarahkan misalnya dalam hal keimanan, ibadah, seperti tentang pembagian jumlah rakaat shalat dalam setiap waktunya tidak perlu dimusyawarahkan atau ditukar-

${ }^{29}$ Musa, Niżām al-Hukm fì al-Islām. tukar sesuai dengan kehendak hatinya karena hal ini sudah baku atau qat' $i$.

Permasalahan lain yang muncul jika musyawarah dikaitkan dengan negara adalah siapa yang berhak untuk melaksanakan musyawarah dan menentukan kebijakan pemerintah. Quraish Shihab mengutip sebuah hadits:

Wahai Ali, jangan bermusyawarahah dengan orang penakut, karena dia mempersempit jalan keluar, jangan juga dengan orang kikir, karena dia menghambat engkau dari tujuanmu, juga tidak dengan yang berambisi, karena dia akan memperindah untukmu keburukan sesuatu. Ketahuilah wahai Ali, bahwa takut, kikir, dan ambisi merupakan bawaan yang sama. Semuanya bermuara pada prasangka buruk kepada Allah. ${ }^{30}$

Hadis di atas memberikan pemahaman bahwa untuk melakukan musyawarah sebaiknya tidak dilakukan secara sembarang, ada beberapa hal yang harus dipertimbangkan untuk memilih siapa yang layak diajak bermusyawarah. Hadis di atas juga memberikan petunjuk bahwa tidak semua anggota masyarakat harus dilibatkan dalam proses musyawarah. Sebagai contoh apa yang pernah dilakukan oleh sahabat Nabi ketika melakukan pemilihan siapa yang layak menjadi pengganti Nabi setelah Nabi meninggal. Pada saat itu tidak semua sahabat Nabi diharuskan untuk berkumpul. Hanya sebagian saja yakni sahabat Nabi yang mempunyai kredibilitas tinggi yang diperkenankan hadir. Di samping itu, dilibatkan juga beberapa utusan kepala dari masing-masing suku. Ini membuktikan bahwa musyawarah tidak dilakukan terhadap semua anggota masyarakat. Hanya mereka yang dianggap layak yang berhak untuk mengikuti musyawarah.

Quraish Shihab ketika mengomentari surat Ali Imran: 159 mengatakan bahwa sebenarnya ayat ini telah memberikan arahan kepada kita perihal sikap yang harus diperhatikan ketika hendak bermusyawarah. Ia mengatakan, sedikitnya ada tiga sikap yang harus

\footnotetext{
${ }^{30}$ Shihab, Wawasan Al-Qur'an, 480.
} 
diperhatikan: pertama, adalah sikap lemah lembut. Dalam bermusyawarahah apabila sebagai pemimpin, haruslah ia menghindari tutur kata yang kasar serta sikap keras kepala. Karena jika tidak, maka mitra musyawarah akan meninggalkannya. Kedua, memberi maaf dan membuka lembaran baru sebagaimana kalimat ayat tersebut $f a$ 'fu 'anhum (maafkan mereka). Ketiga, adalah hendaknya selalu menjaga keharmonisan hubungan dengan Tuhan, dengan cara memohon ampunan Ilahi sebagaimana yang dijelaskan oleh ayat tersebut dengan kalimat "wa istaghfir lahum". 31

Jika merujuk pada penjelasan literatur klasik, dijelaskan bahwa mereka yang ditunjuk untuk melakukan musyawarah dalam rangka mencari jalan keluar terhadap permasalahan yang dihadapi umat Islam, disebut oleh AlMawardi dengan Ahl al-Hall wa al-'Aqd (orang yang berhak melepas dan mengikat). Ahl al-Hall wa al-'Aqd adalah sekelompok orang yang mempunyai kualitas tinggi dalam hal penguasaan ilmu pengetahuan, dan dijadikan tempat untuk bertanya dan sekaligus merekalah yang ditugasi untuk melakukan musyawarah dalam rangka mencari solusi terhadap permasalahan yang dihadapi oleh umat Islam baik itu dalam permasalahan yang dihadapi negara atau pun rakyatnya. Atau sebagaimana ungkapan Muhammad 'Abduh yang mengatakan Ahl al-Hall wa al-'Aqd sebagai orang yang menjadi rujukan masyarakat untuk kebutuhan dan kepentingan umum mereka, yang mencakup pemimpin formal maupun non-formal, sipil maupun militer. ${ }^{32}$ Inilah yang membedakan antara shüra dan demokrasi.

Sisi lain perbedaan antara shüra dan demokrasi adalah dalam hal pengambilan keputusan. Menurut Quraish Shihab sedikitnya manusia mengenal tiga cara dalam mengambil keputusan: pertama, keputusan yang ditetapkan oleh penguasa. Kedua, keputusan yang ditetapkan berdasarkan pandangan minoritas. Ketiga, keputusan yang ditetapkan

\footnotetext{
${ }^{31}$ Shihab, Wawasan Al-Qur'an, 473-475.

${ }^{32}$ Dikutip oleh Shihab, Wawasan Al-Qur'an, 481.
}

berdasarkan pandangan mayoritas. Dari tiga model keputusan ini maka Quraish mengatakan bahwa konsep shüra dalam Islam tidak tepat jika mengambil model yang pertama di atas. Tidak hanya itu, model kedua pun menurutnya tak pantas bagi konsep shüra. Ia berkata: jika suara minoritas menjadi pilihan, apa keistimewaan pendapat minoritas sehingga menjadi pilihan? Sebagai jawabannya ia merasa cocok dengan model ketiga, akan tetapi hal itu tidaklah mutlak. Untuk memperkuatnya, ia mengutip ungkapan Ahmad Kamal Abu al-Majid yang mengatakan bahwa keputusan janganlah langsung diambil berdasarkan pandangan mayoritas setelah melakukan sekali dua kali musyawarah, tetapi hendaknya berulang-ulang hingga dicapai kata sepakat. ${ }^{33}$

Meskipun begitu, menurut penulis, dalam konsep shüra proses pengambilan keputusan tidak mesti ditentukan dengan suara mayoritas. Ada kalanya suara minoritas justru yang dipilih, hal ini disebabkan mungkin suara minoritas yang lebih tepat untuk dipilih. Kondisi ini pernah terjadi pada masa Khalifah Abu Bakar. Pada waktu itu Khalifah pernah mengabaikan pendapat suara mayoritas dalam hal sikap terhadap para pembangkang pembayar zakat. Pada saat itu sebagian mayoritas sahabat yang dimotori oleh Umar Ibn Khatab berpendapat bahwa orang-orang yang menolak membayar zakat tetaplah dikatakan Muslim dan tidak boleh diperangi. Akan tetapi Khalifah Abu Bakar pada waktu itu tetap memilih untuk memerangi mereka yang enggan membayar zakat sekaligus menolak mereka yang menghendaki untuk tidak memeranginya sebagaimana dimotori oleh Umar. Pendapat Abu Bakar pun kemudian disetujui oleh forum dan realisasi kebijakan Khalifah pun berjalan dalam sejarah.

Kondisi penolakan atas suara mayoritas pun pernah dilakukan pada masa Khalifah Umar. Saat itu permasalahan yang menjadi agenda musyawarah adalah perihal harta rampasan perang (ghanimah) berupa tanah. Pada saat sebagian sahabat menghendaki agar

\footnotetext{
${ }^{33}$ Shihab, Wawasan Al-Qur'an, 482-483.
} 
harta yang dimiliki oleh mereka yang kalah berperang dirampas dan kemudian dibagikan kepada mereka yang mengikuti peperangan. Alasan mereka karena cara seperti ini diajarkan oleh Nabi dan juga dipraktekkan pada masa Khalifah Abu Bakar. Kebijakan ini kemudian ditentang oleh Khalifah Umar. Umar dan beberapa sahabat minoritas menghendaki agar harta rampasan itu tidak disita, akan tetapi dikembalikan lagi kepada mereka sebagai pemilik sah dan umat Islam hanya boleh memungut pajaknya saja. Dan pada akhirnya kebijakan Umar pun disetujui oleh semua sahabat dan hal itu terrealisasi juga dalam sejarah.

Dari adanya beberapa pendapat di atas, yang terpenting dalam konsep shüra adalah seberapa besar nilai kebaikan dari pendapatpendapat tersebut-baik itu dari minoritas maupun mayoritas. Jika ternyata pendapat minoritas yang lebih banyak manfaatnya, maka ia pun menjadi pilihan, begitu sebaliknya. Inilah menurut penulis di antara sisi perbedaan lainnya dengan demokrasi yang mensyaratkan bahwa hanya suara mayoritaslah yang menjadi pilihan.

Begitu pentingnya konsep shüra dalam sebuah negara membuat konsep ini dijadikan oleh Jumhur Ulama sebagai syarat bagi seseorang yang akan diangkat menjadi seorang pemimpin negara. Menurut Jumhur Ulama, proses pemilihan seorang pemimpin negara haruslah dengan jalan musyawarah. Lalu pertanyaannya bagaimana mekanisme menjalankan musyawarah dalam memilih pemimpin negara dalam dunia realitas. Dalam hal ini para ulama menentukan tiga cara, ${ }^{34}$ Pertama, pemilihan secara bebas melalui musyawarah tanpa pencalonan lebih dahulu oleh seseorang. Menurut para ulama, hal ini pernah dicontohkan ketika pemilihan Abu Bakar. Ia dipilih secara bebas tanpa dipersiapkan oleh Rasulullah Saw untuk menjadi penggantinya. Kedua, Khalifah mempersiapkan putra mahkota sebagai penggantinya jika antara keduanya tidak ada hubungan keluarga. Cara

\footnotetext{
${ }^{34}$ Muhammad Abu Zahrah, Aliran Politik dan 'Aqidah dalam Islam, terj. Abd. Rahman Dahlan dan Ahmad Qarib (Jakarta: Logos, 1996), 95-96.
}

ini pernah dicontohkan oleh Abu Bakar ketika memilih Umar. Pengangkatan putra mahkota ini sifatnya pengajuan calon saja dari Abu Bakar dan bukan suatu kemestian. Ketiga, mempersiapkan salah seorang dari tiga orang atau lebih anggota masyarakat yang dipandang terbaik di dalam masyarakat. Dan cara yang ketiga ini nampaknya menjadi pilihan setiap negara di dalam memilih pemimpinnya.

\section{Hubungan Islam dan Demokrasi: Kasus Indonesia}

Setelah di atas kita memfokuskan pada kajian seputar makna dari demokrasi dan syura, dan beberapa tipologi pandangan intelektual Muslim terhadap isu demokrasi, pada bagian ini akan coba disajikan potret penerapan demokrasi dengan mengambil sampel kasus di Indonesia.

Pengambilan kasus Indonesia dalam hal ini sangat menarik karena dua alasan; pertama, Indonesia dilihat dari kuantitas jumlah adalah penganut agama Islam mayoritas di dunia dibandingkan negara-negara berpenduduk Islam lainnya. Kedua, dalam kasus penerapan demokrasi, Indonesia adalah negara paling berhasil dalam menerapkan isu demokrasi. ${ }^{35}$

Dalam memotret kasus Indonesia ini, penulis berdasar pada penemuan Saiful Mujani melalui riset disertasinya yang kemudian dibukukannya dengan judul "Muslim Demokrat; Islam, Budaya Demokrasi, dan Partisipasi Politik di Indonesia Pasca Orde Baru". ${ }^{36}$ Buku yang ditulis oleh Saiful Mujani ini ${ }^{37}$ adalah sebuah bantahan bagi mereka yang mengatakan bahwa Islam atau masyarakat Islam tak sesuai dengan demokrasi atau tak akan bisa mene-rima konsep penerapan demokrasi.

\footnotetext{
${ }^{35}$ Saiful Mujani, Muslim Demokrat: Islam, Budaya Demokrasi, dan Partisipasi Politik di Indonesia Pasca Orde Baru, (Jakarta: Gramedia Pustaka Utama, 2007).

${ }^{36}$ Mujani, Muslim Demokrat: Islam, Budaya Demokrasi, dan Partisipasi Politik di Indonesia Pasca Orde Baru.

${ }^{37}$ Buku ini pada awalnya adalah sebuah disertasi untuk memperoleh gelar doktor dalam ilmu politik dari Departemen Ilmu Politik, di The Ohio State University, Colombus, Amerika Serikat.
} 
Ada banyak ilmuwan yang mengatakan bahwa Islam cenderung akan menolak istilah dan penerapan demokrasi. Di antaranya adalah Samuel P. Huntington yang mengatakan bahwa bila orang Islam berusaha memperkenalkan demokrasi ke dalam masyarakat mereka, usaha itu cenderung akan gagal karena Islam, yang sangat berpengaruh dalam kehidupan mereka, tidak mendukung demokrasi. Lebih lanjut ia berpendapat bahwa kegagalan demokrasi di negara-negara Muslim antara lain disebabkan oleh watak budaya dan masyarakat Islam yang tidak ramah terhadap konsep-konsep liberalisme Barat. ${ }^{38}$

Pandangan serupa pun dikumandangkan oleh Elie Kedourie. Ia menyatakan bahwa ajaran, norma, kecenderungan, pengalaman keseharian orang Islam telah membentuk pandangan politik kaum Muslimin yang khas dan jauh dari modern. Menurutnya peradaban Islam bersifat unik; kaum Muslim bangga akan warisan masa lalu mereka dan bersikap tertutup terhadap dunia luar. Peradaban seperti ini menurutnya akan menghambat kaum Muslim untuk mempelajari dan menghargai kemajuan politik dan sosial yang dicapai oleh peradaban lain. ${ }^{39}$ Pendapat senada pun diungkapkan oleh Bernard Lewis. ${ }^{40}$

Beberapa pandangan di atas yang sedikit menyentil Islam terbantahkan jika kita berkaca pada kasus Indonesia. Berdasarkan riset Saiful Mujani ditemukan bahwa meskipun mayoritas penduduk Indonesia beragama Islam, ternyata masyarakat Islam Indonesia cukup menarik dengan penerapan demokrasinya. Meskipun buku ini tidak bisa secara total menggugurkan teori Elie Kedourie, Bernard Lewis, dan Samuel P Huntington karena masih banyak negara-negara mayoritas muslim lainnya yang cenderung membenarkan pandangan tokoh di atas, akan tetapi minimal kehadiran buku ini bisa sedikit dijadikan cacatan bahwa ternyata

\footnotetext{
${ }^{38}$ Samuel P Huntington, The Clash of Civilizations. Remaking of The World Order (New York: Simon and Schuster, 1997), 112.

${ }^{39}$ Elie Kedourie, Democracy and Arab Political Culture (Portland: Frank Cass, 1994).

${ }^{40}$ Bernard Lewis, What Went Wrong? Western Impact and Middle Eastern Response (Oxford: Oxford University Press, 2002), 100.
}

ada juga negara yang mayoritas muslim mendukung secara baik penerapan demokrasi, dan negara itu adalah Indonesia.

Jika kita membaca buku ini, istilah demokrasi dipahami melalui dua cara; sebagai sebuah kompleks budaya politik dan sebagai partisipasi politik. Sebagai sebuah konsep budaya politik, demokrasi mencakup unsurunsur saling percaya antar sesama warga (interpersonal trust), jaringan keterlibatan kewargaan (networks of civic engagement), toleransi, keterlibatan politik, kepercayaan pada institusi politik, kepuasan terhadap kinerja demokrasi, dukungan terhadap prinsipprinsip demokrasi, dan dukungan terhadap masyarakat politik modern, yakni negarabangsa (nation-state). Sebagai partisipasi politik, demokrasi merupakan seperangkat aksi politik yang bersifat sukarela-mulai dari voting hingga protes - oleh warga negara biasa dengan tujuan mempengaruhi kebijakan publik. $^{41}$

Buku yang ditulis oleh saudara Saeful Mujani ini mencoba membuktikan apakah Islam mempunyai hubungan negatif dengan demokrasi. Ada sekitar sepuluh hipotesis yang akan dibuktikan dalam buku ini;

Pertama, "semakin Islami seorang Muslim, ia semakin cenderung tidak percaya kepada orang lain pada umumnya". 42 Berdasarkan hasil penelitian di Indonesia, hipotesis tersebut tidak menemukan pembuktiannya. Tidak ada satu pun unsur Islam yang memiliki korelasi negatif dan signifikan dengan sikap saling percaya pada orang lain pada umumnya. ${ }^{43}$

Kedua, "semakin Islami seorang Muslim, ia akan semakin cenderung tidak percaya kepada non-Muslim”. Dalam kasus kaum Muslim Indonesia hipotesis ini tertolak. Tidak ada satu pun unsur Islam, kecuali "Islamisme" yang memiliki korelasi negatif dan signifikan dengan faktor kepercayaan terhadap non-

\footnotetext{
${ }^{41}$ Mujani, Muslim Demokrat: Islam, Budaya Demokrasi, dan Partisipasi Politik di Indonesia Pasca Orde Baru, 313.

42 Untuk lebih jelasnya terkait dengan data penelitian ini dapat dilihat pada halaman 117-149.

${ }^{43}$ Mujani, Muslim Demokrat: Islam, Budaya Demokrasi, dan Partisipasi Politik di Indonesia Pasca Orde Baru, 315.
} 
Muslim. Baik didefinisikan sebagai kepercayaan terhadap orang lain secara umum maupun terhadap non-Muslim. Islam secara keseluruhan tidak berpengaruh terhadap tinggi rendahnya kepercayaan antar sesama warga. Rendahnya kepercayaan antar sesama warga di kalangan Muslim Indonesia tidak memiliki korelasi signifikan dengan Islam. ${ }^{44}$

Ketiga, "semakin Islami seorang Muslim, cenderung semakin rendah pula keterikatannya dalam aktivitas kewargaan yang bersifat sekular". Hipotesis ini untuk Indonesia tidak meyakinkan. Tidak ada satu pun unsur Islam yang memiliki korelasi negatif dan signifikan dengan jaringan keterlibatan dalam perkumpulan sekular. Sebaliknya, hampir semua unsur Islam memiliki korelasi positif, signifikan, dan konsisten dengan jaringan keterlibatan tersebut. Karena itu untuk kasus Indonesia, Islam ternyata memperkuat, bukan memperlemah, keterlibatan kaum Muslim dalam perkumpulan kewargaan yang bersifat sekular. $^{45}$

Keempat, "semakin Islami seorang Muslim, ia semakin cenderung tidak toleran terhadap orang Kristen". 46 Hipotesis ini jika dilihat secara empirik di lapangan terlihat mempunyai pembuktiannya. Respon bagi kelompok Islamis memiliki korelasi negatif, signifikan dan konsisten dengan sikap toleran terhadap orang Kristen. Akan tetapi untuk kasus ini, Saeful Mujani menyatakan bahwa untuk kasus kaum Muslim Indonesia, Islamisme tidak identik dengan Islam. Karena itu, toleransi dalam hal ini lebih baik diukur dengan sikap toleran terhadap kelompok yang paling tidak disukai, dan bukan diukur dengan sikap toleran terhadap kelompok tertentu seperti Kristen. Karena dengan pengertian toleransi politik seperti ini, lebih sensitif terhadap persoalan konsolidasi demokrasi. Karena itu klaim bahwa Islam memiliki korelasi negatif

\footnotetext{
${ }^{44}$ Mujani, Muslim Demokrat: Islam, Budaya Demokrasi, dan Partisipasi Politik di Indonesia Pasca Orde Baru, 315.

${ }^{45}$ Mujani, Muslim Demokrat: Islam, Budaya Demokrasi, dan Partisipasi Politik di Indonesia Pasca Orde Baru, 316.

${ }^{46}$ Untuk lebih jelasnya terkait dengan data penelitian ini dapat dilihat pada halaman 153-186.
}

dengan konsolidasi demokrasi, karenanya, harus diukur dengan melihat sejauh mana Islam memiliki korelasi negatif dengan toleransi politik secara umum tersebut. Karena itu hipotesisnya adalah; "semakin Islami seorang Muslim, ia semakin cenderung tidak toleran terhadap kelompok yang paling tidak disukainya”. Untuk kasus Indonesia, hipotesis ini tidak terbukti. Karena tidak ada satu pun unsur Islam yang memiliki korelasi negatif dan signifikan dengan sikap toleran terhadap kelompok yang paling tidak disukai. Sebaliknya, jaringan keterlibatan dalam perkumpulan Islam memperlihatkan korelasi yang relatif signifikan dan positif dengan toleransi politik secara umum. ${ }^{47}$

Kelima, "semakin Islami seorang Muslim, ia semakin cenderung tidak terlibat dalam politik". ${ }^{48}$ Untuk kasus ini, Saeful Mujani melihat dari keterilabatn umat Islam dalam mengikuti berita politik; baik melalui media massa, diskusi politik dan perasaan pentingnya menentukan sikap dalam proses politik. Untuk kasus Indonesia, hipotesis ini ternyata juga tidak terbukti secara empiris. Tidak ada satu pun unsur Islam yang memiliki korelasi negatif dan signifikan dengan unsur keterlibatan politik. Sebaliknya, beberapa unsur Islam, seperti: ibadah, memiliki korelasi yang signifikan, langsung, konsisten, dan positif dengan keterlibatan politik. Kesimpulan akhir, justru Islam membantu mengintegrasikan para penganutnya dengan sistem demokrasi melalui keterlibatan politik. $^{49}$

Keenam, "semakin Islami seorang Muslim, ia semakin cenderung tidak percaya pada institusi politik". Dari hasil survai ditemukan bahwa ternyata bahwa tak satu pun unsur Islam yang memiliki korelasi negatif dan signifikan dengan lemahnya tingkat kepercayaan pada institusi politik. Sebaliknya,

\footnotetext{
${ }^{47}$ Mujani, Muslim Demokrat: Islam, Budaya Demokrasi, dan Partisipasi Politik di Indonesia Pasca Orde Baru, 317.

${ }^{48}$ Untuk lebih jelasnya terkait dengan data penelitian ini dapat dilihat pada halaman 189-217.

${ }^{49}$ Mujani, Muslim Demokrat: Islam, Budaya Demokrasi, dan Partisipasi Politik di Indonesia Pasca Orde Baru, 318.
} 
ada sejumlah indikasi yang menegaskan bahwa Islam memiliki korelasi yang positif dan signifikan dengan kepercayaan pada institusi ini. Lebih lanjut ia menyatakan bahwa dari sudut pandang stabilitas demokrasi, ternyata tidak ada indikasi bahwa Islam dapat mengakibatkan destabilitasi pemerintahan demokrasi. Justru sebaliknya Islam memiliki kontribusi positif. $^{50}$

Keenam, "semakin Islami seorang Muslim, ia semakin cenderung tidak puas terhadap kinerja demokrasi". Dari hasil survai ditemukan ternyata tidak ada satu pun unsur Islam yang memiliki korelasi negatif dan signifikan dengan kepuasan terhadap kinerja demokrasi. Ternyata dari sini dapat disimpulkan bahwa tingkat kesalehan kaum Muslim Indonesia ternyata tidak terkait dengan evaluasi mereka terhadap kinerja demokrasi sebuah pemerintahan. ${ }^{51}$

Ketujuh, "semakin Islami seorang Muslim, ia semakin cenderung tidak mendukung prinsip-prinsip demokrasi". ${ }^{2}$ Untuk kasus Indonesia, ternyata hipotesis ini tidak terbukti secara empiris. Tidak ada satu pun unsur Islam yang memiliki korelasi negatif dan signifikan dengan dukungan terhadap prinsip-prinsip demokrasi. Bahkan Saeful Mujani menemukan bahwa sikap kalangan Islamis pun yang diduga kuat memiliki korelasi negatif, ternyata tidak terbukti. Lebih lanjut ia menyatakan bahwa Islam ternyata mempunyai dan memiliki potensi untuk memperkuat demokrasi, seperti tentang ijtihàd, ijmā', ikhtilāf, dan shüra. ${ }^{53}$

Kedelapan,"semakin Islami seorang Muslim, ia semakin cenderung tidak mendukung negara-bangsa”. Dari hasil penelitian juga ditemukan bahwa ternyata hipotesis ini

\footnotetext{
${ }^{50}$ Mujani, Muslim Demokrat: Islam, Budaya Demokrasi, dan Partisipasi Politik di Indonesia Pasca Orde Baru, 318.

${ }^{51}$ Mujani, Muslim Demokrat: Islam, Budaya Demokrasi, dan Partisipasi Politik di Indonesia Pasca Orde Baru, 319.

${ }^{52}$ Untuk lebih jelasnya terkait dengan data penelitian ini dapat dilihat pada halaman 221-250.

${ }^{53}$ Mujani, Muslim Demokrat: Islam, Budaya Demokrasi, dan Partisipasi Politik di Indonesia Pasca Orde Baru, 320.
}

tidak terbukti secara empiris karena tidak ada satu pun unsur Islam yang memiliki korelasi negatif dan signifikan dengan dukungan terhadap negara-bangsa Indonesia. ${ }^{54}$

Kesembilan,"semakin Islami seorang Muslim, cenderung semakin kecil partisipasinya dalam politik, kecuali jika objek dari partisipasinya itu bersifat keislaman". ${ }^{55}$ Dari hasil pengamatan ternyata hipotesis itu tidak terbukti untuk kasus kaum Muslim Indonesia. Karena tidak ada satu pun unsur Islam yang memiliki korelasi negatif dan signifikan dengan partisipasi politik, terlepas dari apa pun objek partisipasinya, entah bersifat keagamaan atau pun non-keagamaan.

Kesepuluh,"semakin Islami seorang Muslim, cenderung semakin kecil kemungkinannya untuk menjadi warga yang setia, dan semakin besar kemungkinannya untuk menjadi warga yang teralienasi, naif, dan apatis". Dari hasil survai, hipotesis ini ternyata tidak terbukti. Untuk kasus umat Islam Indonesia, warga negara yang setia dan teralienasi relatif lebih aktif dalam semua bentuk partisipasi politik-yang terlembagakan dan yang tidak terlembagakan, yang konvensional dan yang non-konvensional-dibanding warga negara yang naif dan apatis. Lebih lanjut ia menemukan bahwa dikalangan warga yang setia, tidak ada satu pun unsur Islam yang memiliki korelasi negatif dengan statusnya sebagai warga yang setia. ${ }^{56}$

Dari penelitian di atas, Saeful Mujani menyimpulkan bahwa ternyata tidak ada satu pun unsur Islam yang memiliki korelasi negatif dan signifikan dengan satu unsur demokrasi. Keseluruhan proposisi bahwa Islam memiliki korelasi negatif dengan demokrasi jika mengacu pada hasil survai kaum Muslim Indonesia terbantahkan. Berdasarkan data ini, maka pendapat mereka yang menyatakan bahwa Islam mempunyai

\footnotetext{
${ }^{54}$ Mujani, Muslim Demokrat: Islam, Budaya Demokrasi, dan Partisipasi Politik di Indonesia Pasca Orde Baru, 321.

${ }^{55}$ Untuk lebih jelasnya terkait dengan data penelitian ini dapat dilihat pada halaman 253-292.

${ }^{56}$ Mujani, Muslim Demokrat: Islam, Budaya Demokrasi, dan Partisipasi Politik di Indonesia Pasca Orde Baru, 323.
} 
korelasi negatif dengan demokrasi dengan mengacu pada pandangan kaum Muslim Indonesia terbantah atau secara otomatis gugur.

\section{SIMPULAN}

Dari uraian di atas, menurut hemat penulis, bahwa antara demokrasi dan shüra banyak sekali titik persamaannya meskipun juga ada beberapa celah perbedaannya. Lalu mengapa kita mesti takut menerima konsep demokrasi? Menurut hemat penulis, menolak demokrasi dengan alasan bahwa istilah ini datang dari Barat dan syarat akan muatan misi dan demokrasi juga dianggap lebih mengusung sisi mayoritas dan meninggalkan minoritas, adalah pendapat yang keliru (tidak objektif). Bukankah kita telah diajarkan oleh Nabi kita bahwa mencari hikmah boleh di mana saja. Dan hikmah itu mungkin saja datang dari negeri Barat - tidak selamanya dari Timur (negara bermayoritas muslim). Sudahkah kita menyadari bahwa terkadang kita juga secara tidak disadari bersikap ala demokrasi, seperti dalam masalah mencari argumentasi dalam bidang fikih (hukum Islam) misalnya. Kita selalu mengatakan bahwa "hendaklah dalam mencari dan mengikuti sebuah ketentuan hukum selalu berpatokan kepada jumhur ulama atau mayoritas pendapat ulama sebagai pegangan". Jika mereka bersikap seperti ini, berarti mereka juga (yang menolak demokrasi) secara tidak disadari menjalankan "ajaran" demokrasi.

Menurut hemat penulis, apakah pendapat ulama yang minoritas itu salah, tentunya tidak atau belum tentu bukan. Karena itu, pemikiran yang bijak haruslah menjadi acuan dan pegangan, baik dalam melihat permasalahan demokrasi atau pun yang lainnya.Untuk kasus umat Islam Indonesia berdasarkan penelitian Saeful Mujani dalam bukunya "Muslim Demokrat" ternyata umat Islam Indonesia begitu menerima dan berhubungan positif dengan konsep demokrasi yang selama ini dianggap "mahluk asing" dan bertentangan dengan ajaran Islam. Wallahu a'lam.

\section{DAFTAR PUSTAKA}

Al-Qardhawy, Yusuf. Fiqih Daulah; Dalam Perspektif Alquran dan Sunnah. Diterjemahkan oleh Kathur Suhardi. Jakarta: Pustaka al-Kautsar, 1997.

Al-Syawi, Taufiq. Syura Bukan Demokrasi. Diterjemahkan oleh Djamaluddin ZS. Jakarta: Gema Insani Press, 1997.

Al-Nabhani, Taqiyuddin. Nizam Al-Islām. t.k.: t.p., 2001.

Esposito, John L. Islam dan Politik. Jakarta: Bulan Bintang, 1990.

Esposito, John L., dan James P. Piscatori. "Islam and Democracy." Middle East Journal VL, no. III (1991).

. "Islam dan Demokrasi." Islamika, Jurnal Dialog Pemikiran Islam April-Janu, no. 4 (1994).

Esposito, John L., dan John O. Voll. Demokrasi di Negara-Negara Muslim. Bandung: Mizan, 1999.

Ghafar, Afan. "Demokratisasi dan Prospeknya di Indonesia Orde Baru." Di Demokratisasi Politik, Budaya dan Ekonomi; Pengalaman Indonesia Masa Orde Baru, diedit oleh Elza Peldi Taher. Jakarta: Paramadina, 1994.

Heikal, Muhammad Husein. Pemerintahan Islam. Diterjemahkan oleh Tim Pustaka Firdaus. Jakarta: Pustaka Firdaus, 1993.

Huntington, Samuel P. The Clash of Civilizations: Remaking of The World Order. New York: Simon and Schuster, 1997.

Huwaidi, Fahmi. Demokrasi, Oposisi, dan Masyarakat Madani. Diterjemahkan oleh M. Abdul Ghofar. Bandung: Mizan, 1996.

Huwaydi, Fahmi. Al-Islām wa alDemuqrätīyah. Kairo: Markaz al-Ahram, 1993.

Kamil, Sukron. Islam dan Demokrasi; Telaah Konseptual dan Historis. Jakarta: Gaya Media Pratama, 2002.

Kedourie, Elie. Democracy and Arab Political Culture. Portland: Frank Cass, 1994.

Lewis, Bernard. What Went Wrong? Western Impact and Middle Eastern Response. Oxford: Oxford University Press, 2002. 
Maarif, Muhammad Syafi'i. Islam dan Masalah Kenegaraan. Jakarta: LP3ES, 1985.

Magnis-Suseno, Franz. "Demokrasi Tantangan Universal." Di Agama dan Dialog Antar Peradaban, diedit oleh M. Nasir Tamara dan Elza Peldi Taher. Jakarta: Paramadina, 1996.

Manzūr, Ibn. Lisānul 'Arab. Jilid 4. Beirut: Dār al-Shadr, 1968.

Memon, Ali Nawaz. "Membincang Demokrasi." Di Islam Liberalisme Demokrasi, diterjemahkan oleh Mun'im A. Sirry. Jakarta: Paramadina, 2002.

Mujani, Saiful. Muslim Demokrat: Islam, Budaya Demokrasi, dan Partisipasi Politik di Indonesia Pasca Orde Baru,. Jakarta: Gramedia Pustaka Utama, 2007.

Musa, Muhammad Yusuf. Nizām al-Hukm fí al-Islām. Kairo: Dār al-Katib al-'Arabì, t.t.

Rahardjo, Dawam. "Syura." Jurnal Ulumul Qur'an 1, no. 1 (1989).

Sammarah, Iḥsān. Mafhūm Al-'Adālah AlIjtimaiyah fí Al-Fikrì Al-Islāmì Al-Mu'asir. Bairut: Dār Al-Nahḍah Al-Islāmiyah, 1991.

Shihab, Muhammad Quraish. Wawasan Alquran. Bandung: Mizan, 1996.
Sihbudi, Riza. "Bahasa dalam Kelompok Syi'ah, Kasus Vilayat Faqih." Islamika, Jurnal Dialog Pemikiran Islam, no. 5 (1994).

-. "Masalah Demokratisasi di Timur Tengah." Di Agama, Demokrasi, dan keadilan, diterjemahkan oleh M. Imam Aziz. Jakarta: Gramedia, 1993.

Sulaiman, Sadek J. "Demokrasi dan Shura." Di Islam Liberal, diedit oleh Charles Khurzman, diterjemahkan oleh Bahrul Ulum dan Heri Junaedi. Jakarta: Paramadina, 2003.

Zahrah, Muhammad Abu. Aliran Politik dan 'Aqidah dalam Islam. Diterjemahkan oleh Abd. Rahman Dahlan dan Ahmad Qarib. Jakarta: Logos, 1996. 